\title{
O COLÉGIO DE LÍDERES: SURGIMENTO E EVOLUÇÃO
}

\author{
Juliana Baldoni Figueiredo *
}

Resumo: Este artigo discute o funcionamento do Colégio de Líderes e seus efeitos sobre a atividade legislativa da Câmara dos Deputados. Para isso, a pesquisa se baseou em artigos científicos sobre o tema e documentos que demonstram o que motivou a criação do colegiado, como ele se reúne e de que modo ele colabora para a definição da pauta de votações do Plenário. Incluindo entrevistas com figuras que participaram ativamente da criação e da evolução do Colégio de Líderes no cenário político, este trabalho descreve de que forma a sua atuação limita a representatividade parlamentar e que soluções poderiam ser adotadas para amenizar esse conflito, já que, apesar de colaborar para a concentração de poderes no Congresso Nacional, esse órgão se tornou indispensável para a organização e agilidade dos trabalhos legislativos. Para ilustrar como se dá na prática a atuação do colegiado, procedeu-se a uma análise das reuniões realizadas no primeiro período da sessão legislativa ordinária de 2009, tudo com base em dados fornecidos pela Secretaria-Geral da Mesa da Câmara dos Deputados e em notícias da Agência Câmara divulgadas naquele semestre.

Palavras-chave: Colégio de Líderes; representatividade; líderes partidários; processo legislativo.

\begin{abstract}
This paper discusses the operation of the party Leader's Committeeand their effects on the legislative activity of the Chamber of Deputies. For this, the research was based on scientific articles on the subject and documentation demonstrating what that motivated the creation of the college, as it meets and how it contributes to setting the agenda of the plenary vote. Including interviews with figures who participated actively in the creation and evolution of the College of Leaders in the political arena, this work describes how its performance limits the parliamentary representation and what solutions could be adopted to mitigate this conflict, since, although it works for the concentration of power in Congress, this organ has become indispensable to the organization and agility of legislative work. To illustrate how it happens, in

\footnotetext{
* Graduada em Direito pelo UniCEUB e pós-graduada em Processo Legislativo pelo CEFOR, exerce o cargo de Analista Legislativo na Câmara dos Deputados, onde atua como Taquígrafa Legislativa, lotada no Departamento de Taquigrafia, Revisão e Redação (juliana.figueiredo@camara.gov.br).
} 
practice, the performance of the college, an analysis was performed on the meetings held in the first period of the legislative ordinary session of 2009, all with base on data provided by the General Secretariat of the Board of the Chamber and in news of Agency Chamber disclosed this semester.

Keywords: party Leader's Committee; representation; party leaders; legislative process.

\section{Introdução}

Os registros da atuação de grandes líderes no Parlamento brasileiro datam da época do Império, ainda que, até o início do período republicano, alguns deles se manifestassem na arena política não pela defesa de um partido ou por vinculação à própria atividade parlamentar, mas por exercício cívico. Desde então, destacou-se a participação de líderes que lograram modificar a estrutura de Estado, mas hoje, por buscarem mais a manutenção ou ampliação do poder até então alcançado por sua sigla do que propriamente a mudança da situação vigente, eles se caracterizam por colaborar para o desenvolvimento de um processo lento e contínuo de evolução do cenário legislativo.

Após longo período autoritário imposto pelo regime militar, quando as liberdades parlamentares foram severamente cerceadas, a redemocratização veio inaugurar um novo panorama social e político no país, e já durante a Constituinte, iniciada em 1987, os líderes partidários exerceram relevante e notável função nas negociações engendradas para a elaboração da nova Constituição.

Como resultado de um natural processo de integração e representação dos interesses sociais e como herança desse processo constituinte, em 1989 foi institucionalizado o Colégio de Líderes, cujas atribuições constam em diversos dispositivos espalhados por todo o Regimento Interno da Câmara dos Deputados (RICD). Sua criação teve como objetivo definir os poderes de um órgão que vinha funcionando informalmente na Casa, mas também organizar o processo de votação e oferecer maior dinamismo às atividades em Plenário.

Desde a sua criação, o Colégio de Líderes vem recebendo diversas críticas por contribuir para a excessiva concentração de poderes que se observa no Parlamento brasileiro, mas também é defendido por aqueles que entendem que o Plenário não seria capaz de organizar seus trabalhos sem as discussões prévias conduzidas por um órgão reduzido que, em conjunto com o Presidente da Casa, se responsabilizasse pela elaboração da pauta de votações.

De lá para cá, foram publicados diversos trabalhos científicos relacionados ao tema, mas poucos abordaram com mais profundidade o nascimento do colegiado, seu funcionamento e seus efeitos sobre a atividade parlamentar na Câmara dos Deputados. Nesse particular, o artigo 
pretende descrever o surgimento do Colégio de Líderes, discutindo a sua evolução, o seu funcionamento e a influência de suas decisões sobre a agenda legislativa federal.

Tratando-se de pesquisa bibliográfica, mas com cunho também documental, foram coletados os registros disponíveis na Secretaria-Geral da Mesa da Câmara dos Deputados acerca das reuniões de líderes ocorridas durante o primeiro semestre da sessão legislativa ordinária de 2009 e notícias da Agência Câmara veiculadas no mesmo período. Para o enriquecimento do trabalho, também foram realizadas entrevistas com Mozart Vianna de Paiva, Nelson Jobim e Miro Teixeira.

Inicialmente, o artigo descreve o histórico da liderança parlamentar no Brasil e demonstra a atuação dos líderes no Congresso Nacional durante o regime militar, o período da redemocratização - quando as reuniões entre os líderes assumiram importância central para a promulgação da nova Constituição - e os governos de Fernando Henrique Cardoso e Luiz Inácio Lula da Silva, até os dias atuais.

Em seguida, trata do surgimento do Colégio de Líderes durante a Constituinte, de sua institucionalização no RICD em 1989, sua estrutura e seu funcionamento. Com esteio na opinião de cientistas, técnicos e deputados, discute-se o papel do órgão no cenário legislativo, debatendo sua importância para o desenvolvimento dos trabalhos no Parlamento brasileiro, bem como as críticas e sugestões visando à redução dos efeitos negativos sobre a representação parlamentar decorrentes da atuação do Colégio de Líderes.

Por fim, pretende ilustrar o quanto tenha sido até então descrito teoricamente. Com base nos dados da Secretaria-Geral da Mesa da Câmara sobre as reuniões ocorridas no primeiro semestre de 2009 e nas notícias divulgadas pela Agência Câmara, procura-se demonstrar, na prática, como ocorrem os encontros entre o Presidente e os líderes partidários e como se dá a elaboração da pauta da Ordem do Dia. Busca-se descobrir também em que medida as deliberações do colegiado influenciam as decisões do Plenário.

\section{A liderança parlamentar no Brasil}

Líderes, assim como os acordos por eles engendrados, sempre estiveram presentes como característica inerente ao processo legislativo - tanto é assim que, no Brasil, os registros de sua atuação remontam à época do Império. Já a forma como eles se organizavam e a importância atribuída às suas ações são fatores que sempre oscilaram em função do momento histórico.

Durante todo o Império e nos momentos iniciais da República, quando o Brasil se iniciava na prática parlamentar, muitos líderes surgiram. Nem sempre, contudo, eles desempenharam uma liderança realmente política; por vezes, nem mesmo estavam ligados a partidos. Nesse período, em que uma liderança se caracterizava sobretudo como exercício 
cívico, destacaram-se ilustres figuras de nossa história, como Joaquim Nabuco e Rui Barbosa (RODRIGUES, 1996).

A história nos mostra também que foi sempre maior o destaque dado aos líderes que tencionavam alterar o modelo de Estado então institucionalizado. Para a estabilização de uma nova estrutura governamental, a participação dos líderes partidários sempre foi fundamental. A própria consolidação da República somente foi possível dada a firme atuação desses líderes, fossem eles partidários ou independentes.

Hoje a liderança parlamentar busca tão somente a manutenção ou ampliação do poder angariado pelo partido e a consecução de seus objetivos. O líder passou, portanto, a exercer a função de administrador de sua sigla, buscando sempre mantê-la, pelo menos, na mais elevada posição hierárquica até então conquistada. Por isso, ele tem hoje uma atuação mais discreta, porém não menos relevante, até porque, nas palavras de Soares (1993, p. 334), ele "é, de fato, o gerenciador da adoção das reformas que aos poucos transformam o panorama nacional".

Após o fim do Estado Novo, entre 1946 e 1964, o Parlamento brasileiro sentiu a intensa fragilidade do sistema partidário. Entidades coletivas, tais como os partidos políticos, não figuravam como organismos tão relevantes à atividade parlamentar, tendo em vista as variadas e descentralizadas fontes de distribuição de benefícios a contemplar os redutos eleitorais dos deputados. Como a criação de despesas não era matéria reservada ao Executivo, o Presidente da República dispunha de limitado poder de barganha, e suas decisões eram influenciadas sobremaneira pelas ameaças dos membros dos partidos, individualmente considerados. De acordo com essa dinâmica, os legisladores não dependiam da intermediação de seus partidos para ver suas demandas particularistas atendidas (SANTOS, 2002).

Durante o regime militar, diante de uma política extremamente centralizadora, dominada pelo Executivo, os líderes partidários não ostentavam muitos poderes; por isso, limitavam-se a fazer discursos de resistência ou a intermediar negociações entre membros da sociedade civil e entidades governamentais. Durante esse período de autoritarismo, surgiu uma herança que se manteve até mesmo após iniciada a Assembleia Nacional Constituinte: a atuação discreta dos líderes de partido (BAAKLINI, 1993; SOARES, 1993).

Como meio de dinamizar as votações, já que grande parcela dos parlamentares costumava se ausentar do Plenário, o RICD, modificado em 1972, passou a prever o voto de liderança. Por meio desse expediente, a manifestação dos líderes representava o voto de seus liderados. Alguns autores, como Pertence (1989), o consideravam incompatível com os princípios basilares do mandato legislativo; para outros, como Falcão (1988, p. 252), nem sempre a sujeição partidária indicava autoritarismo, e o voto de liderança servia, à época, como remédio para o "mal de falta de presentes no recinto". 
Com o fim do bipartidarismo — a partir da reforma partidária de 1979 — e do regime militar, o país, aos poucos, voltava à normalidade democrática. Para tanto, foi instalada em 1987 a Assembleia Nacional Constituinte, cujos trabalhos se estenderam até o segundo semestre do ano seguinte, com uma participação mais efetiva das lideranças partidárias.

Uma das instâncias dos trabalhos constituintes era a Comissão de Sistematização, que tinha a atribuição de reunir os relatórios produzidos pelas comissões temáticas em um Anteprojeto de Constituição. Mas essa era uma atividade tão trabalhosa e complexa que as negociações entre os líderes de partido foram fundamentais para a coordenação de todo o processo. Sem os acordos prévios promovidos pelos líderes, muito provavelmente não se chegaria à etapa final, à conclusão do processo de votação, ou se demoraria muito mais para atingi-la (JOBIM, 1994).

Após a promulgação da Constituição de 1988, os partidos brasileiros passaram a apresentar um comportamento mais disciplinado durante as votações nominais em Plenário, ao mesmo tempo em que os líderes demonstraram dispor de mais amplos poderes no encaminhamento de projetos e de maior influência sobre o comportamento dos liderados (SANTOS, 2002).

Toda essa dinâmica se deve, principalmente, à transferência de poderes decisórios ao Executivo, implementada primeiro após o golpe de 1964 e, depois, ratificada pela Constituição de 1988. A previsibilidade do comportamento dos legisladores aparece como consequência da organização dos deputados e da relevância do papel exercido pelos partidos políticos em período mais recente (SANTOS, 2002).

As ameaças individuais por parte dos parlamentares só fazem frente às estratégias governistas quando os legisladores possuem outras fontes, além das decorrentes de concessões do Presidente da República, para a distribuição de benefícios às suas bases eleitorais, o que não se verifica no período pós-1988. O Executivo, desde o golpe de 1964, passou a deter monopólio no que tange à iniciativa em matéria orçamentária (SANTOS, 2002).

Os partidos políticos, então, passaram a ocupar relevante papel no cenário legislativo. São eles que dão o amparo necessário aos representantes para que suas demandas individuais sejam atendidas. Lidando com uma entidade coletiva que congrega diversos parlamentares, o Presidente se vê pressionado a atender às reivindicações do líder partidário, sob pena de perder o apoio de parte de sua base. Toda essa relação caracteriza, para Santos (2002, p. 246), a transição de um "sistema presidencialista faccional" para um "presidencialismo de coalizão racionalizado".

A teoria partidária define o partido como instrumento de dissolução de conflitos que atua como autoridade central. Após o advento da Constituição de 1988 e a institucionalização do Colégio de Líderes no RICD, a estrutura organizacional da Casa concentrou nas mãos dos 
líderes de partidos relevante capacidade decisória. Angariando amplos poderes a partir de prerrogativas regimentais e do controle de informações e benefícios, eles passaram a influenciar diretamente o comportamento dos demais parlamentares (MÜLLER, 2005).

Durante o Governo Fernando Henrique Cardoso, as prerrogativas constitucionalmente asseguradas ao Executivo, aliadas à concentração de poderes nas mãos dos líderes partidários, permitiram ao presidente garantir um modelo institucional que favorecia amplamente a governabilidade. Mas, para aprovar reformas e projetos de âmbito nacional, ele precisou - e conseguiu — ampliar sua base de apoio (FIGUEIREDO, LIMONGI, VALENTE; 1999). Essa dinâmica foi acompanhada pelo Presidente Lula durante seus dois mandatos. Também dispondo de consistente apoio partidário, ele conquistou a aprovação da maioria de seus projetos.

Altamente disciplinados, hoje os deputados que integram a base governista seguem, em geral, a recomendação do líder do Governo. Dissensões no interior da coalizão de apoio ao Presidente ocorrem com muito pouca frequência. A capacidade dos líderes partidários de prever o comportamento em Plenário dos membros de sua sigla é fundamental, portanto, para que se construa esse cenário, no qual o Executivo raramente é derrotado (LIMONGI, 2006).

As lideranças dos partidos da base do Governo promovem amplas negociações partidárias - e não individuais —, garantindo o apoio da maioria à implementação da agenda política do Executivo. Além disso, os líderes costumeiramente utilizam-se de expedientes como a votação simbólica e os requerimentos de urgência, especialmente a "urgência urgentíssima", para patrocinar o sucesso do Governo.

Após um longo período no exercício de uma liderança enfraquecida, os líderes de partido exercem seu papel livremente na democracia atual, sendo certo que sua capacidade representativa é avaliada não só no âmbito do Congresso, mas também na esfera da sociedade civil organizada. Dessa maneira, a ação do líder passou a delinear mais claramente as características e o perfil de seu partido perante a sociedade (SOARES, 1993).

Mas, apesar da livre manifestação das lideranças, elas atuam hoje em função do domínio exercido pelo Presidente da República no que tange à iniciativa legislativa das matérias administrativas e orçamentárias. Por isso, os parlamentares têm a opção de integrar a coalizão governista, controlando as minorias, ou de se manifestar em oposição ao Governo, fiscalizandoo na medida do possível e esperando vencer as próximas eleições presidenciais (LIMONGI, 2006).

\section{O Colégio de Líderes}

\subsection{Origem}

As negociações entre lideranças partidárias sempre ocorreram no Parlamento brasileiro. Como se sabe, cabe aos líderes de partido debater com os demais membros de sua bancada as 
matérias de interesse da sociedade, levar a posição da sigla à discussão com outros líderes e, por fim, defendê-la em Plenário. Esse sistema de procura pelo consenso por parte das lideranças com o fim de costurar acordos e viabilizar uma atividade legislativa tão qualificada quanto dinâmica funcionou de maneira informal, no Brasil, até a institucionalização do Colégio de Líderes no RICD, em 1989.

A iniciativa não só de disciplinar a atuação do colegiado, como também de constituí-lo como órgão da Casa legislativa surgiu da prática iniciada durante os trabalhos da Assembleia Nacional Constituinte, quando os líderes partidários se reuniam para construir acordos em torno das propostas de modificação ao projeto de Constituição. Tais negociações orientavam e organizavam os trabalhos legislativos, de modo a determinar quais matérias seriam levadas a discussão e votação em Plenário. Mas essa dinâmica não foi observada no período inicial da Constituinte; somente foi adotada após a aprovação de um segundo Regimento Interno para a elaboração do projeto de Constituição (GOMES, 2006).

A princípio, ancorados nas regras regimentais, os progressistas, que compunham maioria na Comissão de Sistematização, mas minoria em Plenário, dificultaram sobremaneira as modificações ao projeto de Constituição e o avanço dos trabalhos da Assembleia. Ao fim, o projeto enviado ao Plenário havia sido definido por esse seleto grupo que integrava o órgão responsável por organizar os trabalhos da Constituinte e que, portanto, desempenhava papel decisivo no processo de votação (GOMES, 2006). Daí se formou o Centrão, coalizão de veto que pleiteou a alteração do Regimento Interno, para que as modificações ao projeto de Constituição fossem facilitadas em Plenário. A Resolução $\mathrm{n}^{\circ} 3$ foi aprovada, mas com as novas regras outros problemas emergiram (GOMES, 2006).

As possibilidades de emendar o projeto foram extremamente ampliadas, e o ônus na votação do projeto da Comissão de Sistematização foi invertido: ao invés de se exigir maioria absoluta para a modificação do texto, era necessário esse mesmo quórum para que fosse mantida qualquer parte do projeto. Isso significa que todo o texto produzido pela Comissão de Sistematização, incluindo-se questões consensuais, seria submetido a votação nominal (Gomes, 2006). O processo constituinte se tornou demasiadamente trabalhoso. A solução encontrada foi, então, centralizar as negociações nas mãos dos líderes partidários. Organizando o processo de votação, de fato eles permitiriam a aprovação mais rápida do projeto de Constituição (GOMES, 2006).

A experiência constituinte foi decisiva para o surgimento de um novo comportamento dos líderes em relação à Mesa. Naturalmente, eles passaram a dispor de mais poder e de maior autonomia para se comunicar entre si e tomar decisões importantes, solicitando a participação da Presidência somente para a homologação de acordos já celebrados (JOBIM, 1994).

O processo de votação passou a ser administrado pelos líderes, em comum acordo com o Presidente da Câmara, que perdeu a prerrogativa fundamental da elaboração exclusiva da 
pauta. Isso passou a ser uma discussão acertada pelas lideranças. Para Jobim (2011), o Colégio de Líderes nasceu para formular a pauta e para costurar acordos, afinal, era "um elemento central da administração da discussão do Plenário", já que "antecipava e reduzia o nível da discussão".

Rodrigues (1996) afirma que, após o fim do regime militar, extinguiu-se o voto de liderança, mas o Colégio de Líderes veio a substituí-lo. Nesse sentido também se manifestam Figueiredo e Limongi (1995), ao afirmarem que, apesar de a atuação de cada um desses institutos na arena legislativa se apresentar de modo bastante diverso, a centralização do poder decisório em um seleto grupo de parlamentares, que acabam decidindo pelos demais, é o que assemelha o Colégio de Líderes e o voto de liderança, que vigorava no período autoritário.

As reuniões do colegiado tornavam-se recorrentes, notadamente no período final da Constituinte, como reflexo de um intenso processo de aglutinação política interna. Naturalmente, elas foram amplamente reconhecidas pelos congressistas como recurso eficiente e vitorioso indispensável à conclusão dos trabalhos. Por isso, em 1989, quando discutiam as alterações ao RICD, os parlamentares deliberaram acerca de destaque para votação da emenda de autoria do então Deputado Nelson Jobim que aditava ao Título II da Resolução $\mathrm{n}^{\circ} 17$ da Câmara dos Deputados um capítulo intitulado "Colégio de Líderes".

Era evidente a resistência da Mesa em institucionalizar o colegiado. Para não perder parte de seu poder, preferia ela convocar, discricionariamente, reuniões eventuais. Já entre os parlamentares, a resistência se dava, principalmente, quanto ao voto ponderado dos líderes em função da expressão numérica de suas bancadas, procedimento que deveria ser adotado no caso de não haver consenso nas reuniões do colegiado. Os deputados de partidos menores temiam que as duas maiores agremiações partidárias dominassem a Casa, que se formasse uma ditadura dos dois maiores partidos à época: o PMDB e o PFL.

Ao fim, os parlamentares decidiram pela institucionalização do colegiado como órgão da Casa, e o art. 20 do Regimento Interno passou a dispor (BRASIL, 1989):

Art. 20. Os Líderes da Maioria, da Minoria, dos Partidos, dos Blocos Parlamentares e do Governo constituem o Colégio de Líderes.

$\S 1^{\circ}$ Os Líderes de Partidos que participem de Bloco Parlamentar e o Líder do Governo terão direito a voz, no Colégio de Líderes, mas não a voto.

$\S 2^{\circ}$ Sempre que possível, as deliberações do Colégio de Líderes serão tomadas mediante consenso entre seus integrantes; quando isto não for possível, prevalecerá o critério da maioria absoluta, ponderados os votos dos Líderes em função da expressão numérica de cada bancada.

Diante de um órgão extremamente poderoso que exercia suas funções na informalidade, os deputados poderiam destruí-lo ou regulamentá-lo. Se a primeira opção já não era mais possível, em razão da proporção que as reuniões de líderes haviam atingido, os parlamentares decidiram pela formalização do colegiado, definindo seus poderes regimentalmente. 


\subsection{O papel do colegiado no debate sobre o funcionamento do Congresso Nacional}

Há quem defenda que a combinação entre uma forte tradição presidencialista, a heterogeneidade estrutural e o fracionamento partidário resulte, como consequência irretorquível, em instabilidade democrática e pouca governabilidade, qualquer que seja o quadro político e institucional vigente. Entretanto, conforme exposto por Abranches (1988), tamanha diversidade do sistema político-partidário brasileiro, definido pelo autor como "presidencialismo de coalizão", deve ser controlada por instrumentos criados justamente para aplicação em nossas instituições sui generis, de modo a promover a normalidade democrática e a justiça social.

Estudos recentes baseados em análises empíricas sobre a produção legislativa e o comportamento parlamentar no Congresso Nacional derrubaram a aplicação dominante das teses distributivistas em relação à política brasileira e desabonaram as afirmações de cientistas como Ames (2003), Mainwaring (1993) e Sartori (1993) no sentido de que o sistema partidário brasileiro, ao congregar parlamentares adeptos da patronagem e do clientelismo, seria incapaz de sustentar nossa democracia.

Se assim fosse, a indisciplina e o comportamento individualista dos deputados se sobreporiam ao poder dos coordenadores do processo legislativo, como os membros da Mesa Diretora, os presidentes de comissões e os líderes partidários, e não é essa a dinâmica que se observa. Pelo contrário, são as prerrogativas conferidas pelo RICD aos líderes de partidos políticos que, preconizando ações coletivas em detrimento das individuais, impedem uma ação singular efetiva dos parlamentares sobre o processo legislativo federal. Essa centralização, aliada ao controle da agenda pelo Presidente da Casa, neutraliza o paroquialismo, mantendo a disciplina partidária e permitindo o controle parlamentar.

Inevitável, porém, reconhecer as dificuldades em se manter a almejada ordem democrática em sistema institucional tão heterogêneo. Quintela (2006) comenta que não é fácil conciliar as funções da representação no Congresso. Se, de um lado, a representatividade deve se materializar, de forma que os parlamentares tenham direito a voz, voto e expressão política, em conformidade com o princípio do pluralismo político, a governabilidade também deve ser assegurada, para que o Executivo, como parte vencedora no processo eleitoral, tenha a oportunidade de ver seus projetos efetivados. E, para manter a mencionada governabilidade, é de rigor que a organização do Congresso brasileiro centralize o poder decisório em alguns poucos atores.

O Colégio de Líderes, instância na qual se discute grande parcela dos pedidos de urgência e se elabora a agenda dos trabalhos legislativos, é um exemplo dessa concentração. Os líderes podem pedir verificação de votação em Plenário e urgência na tramitação de projetos, assim como solicitar votações nominais e encerramento de debates, prerrogativas 
procedimentais relevantes que inibem o poder individual dos deputados e sua capacidade de exercer influência sobre a nova legislação.

Desde a sua institucionalização, o colegiado vem recebendo variadas e pesadas críticas por centralizar decisões relevantes no âmbito de sua atuação, e é hoje encarado de maneira controversa: é visto como importante organizador e agilizador dos trabalhos legislativos, mas também é condenado por impor severas restrições à atuação dos parlamentares, alijando a maioria deles do processo de elaboração normativa, e por favorecer a agenda estabelecida pelo Poder Executivo.

É importante esclarecer, contudo, que o Poder Legislativo não possui atuação secundária no processo decisório. Em que pesem as opiniões contrárias, que consideram o Congresso mero homologador das decisões do Executivo, certo é que, não raras vezes, o Governo, após debates intensos com as lideranças, deixa de enviar ao Legislativo matérias polêmicas cuja aprovação tenha se mostrado improvável (CINTRA, LACOMBE, 2007). Isso tem ocorrido, por exemplo, no caso da criação do imposto sobre grandes fortunas.

É bem verdade que o Executivo exerce relevante influência sobre as votações no Plenário da Câmara, principalmente em função da reiterada utilização do recurso de urgência pelos líderes visando incluir matérias em pauta (Amaral, 2009). Mas esse privilégio é conquistado à custa de muita negociação com os legisladores. As proposições de interesse do Governo que chegam à apreciação do Plenário costumam ser discutidas exaustivamente entre os líderes, e, com frequência, a maioria para a aprovação desses projetos é alcançada votação a votação, após inúmeras concessões feitas de ponta a ponta, tanto entre os Poderes quanto entre líderes e liderados.

A força do Colégio de Líderes nem sempre foi a mesma, oscilando em função dos momentos vividos pelo Parlamento. Jobim (2011) menciona, por exemplo, que o poder das lideranças foi extremamente enfraquecido após a eleição de Severino Cavalcanti para Presidente da Câmara. Atualmente, ele considera que, se movimentos organizados dentro do Parlamento, como a bancada ruralista e as frentes parlamentares, rivalizam com o Colégio de Líderes, isso é consequência imediata da fragilidade imposta às lideranças a partir da eleição de Severino Cavalcanti, já que, naquele período, o Presidente da Casa tomou para si atribuições que antes eram de responsabilidade dos líderes de partido, que tiveram seus poderes diminuídos.

Para o Deputado Miro Teixeira (2011), a eleição de Severino Cavalcanti de fato enfraqueceu o Colégio de Líderes, mas foi exatamente a relativa perda de poderes dos líderes que provocou a retirada de Severino da Presidência e, mais importante que isso, permitiu a diluição do poder dentro do Parlamento brasileiro, uma descentralização necessária para que a soberania popular pudesse se expressar de forma cada vez mais visível e mais clara. 
O Deputado afirma também que, durante muitos anos, se posicionou contra a constituição de frentes parlamentares. Isso porque, em sua opinião, a atuação delas não se mostra decisiva para as deliberações em Plenário, já que os legisladores se interessam muito mais pela proteção dos interesses de sua base eleitoral que pela defesa dos objetivos das frentes parlamentares. Mas, posteriormente, Miro Teixeira passou a assinar os requerimentos de constituição dessas frentes justamente para limitar o poder do Colégio de Líderes, porque enxergou nelas um antídoto para a tendência crescente de centralização das decisões.

Por outro lado, o Colégio de Líderes passa a ter maior influência à medida que o sistema partidário se fortalece, já que o robustecimento dos partidos favorece o controle da ação coletiva por parte das lideranças. A partir de 2007, duas medidas importantes atuaram em favor desse fortalecimento: a vinculação do critério da proporcionalidade partidária aos resultados das eleições, o que determina a perda de cargos em comissões e na Mesa Diretora em virtude de migrações entre siglas, e a decisão do TSE no sentido de que o mandato é do partido, e não do parlamentar.

São frequentes os juízos negativos emitidos por acadêmicos e pesquisadores, como também por boa parte dos parlamentares, em relação ao funcionamento do Colégio de Líderes. Em 1991, pouco depois de haver sido institucionalizado, deputados da Comissão de Modernização da Câmara dos Deputados sugeriram a sua extinção, mas a proposta não alcançou êxito. A sedimentação até então alcançada pelo órgão impediu que tal intento viesse a se concretizar (Figueiredo, 1995).

Entre os cientistas, Figueiredo (1995) se destaca por defender uma reforma institucional que promova a extinção do Colégio de Líderes e a atribuição de maiores poderes às comissões temáticas, já que, para ela, somente o Congresso pode resolver o seu problema interno de centralização decisória.

O ex-Deputado Prisco Viana, adepto do sistema anterior à existência do Colégio de Líderes - quando as lideranças negociavam entre si e cada uma delas levava sua posição à respectiva bancada, sustentando em Plenário suas decisões - , critica o fato de as reuniões de líderes ocorrerem à revelia dos demais parlamentares componentes da sigla. Repreende também o sistema de concessões recíprocas que resultam das reuniões do colegiado (Viana, 1994).

O Deputado Miro Teixeira, em seminário do CEBRAP no ano de 1994, afirmou que, quando não existia o Colégio de Líderes, as discussões eram mais vivas, e o deputado não era "um apertador de botão". O parlamentar assim também se manifestou (VIANA, 1994, p. 33):

Então não se pode admitir que, quando os líderes se reúnem com a Presidência, não se saiba como foi convocado, de que maneira, com que antecedência, com que pauta. Só eles sabem. (...) Sou contra esse tipo de procedimento porque isso deixa no plenário o conjunto dos deputados exatamente como descreveu o deputado Prisco Viana, na expectativa do que vai ser descrito nessa reunião. O deputado entra no plenário e pergunta: o que vai ser votado? E logo em seguida: Como é que nós votamos? Sim ou não? 
Não se pode, portanto, responsabilizar esse deputado, porque ele é massacrado por uma estrutura na qual ele não participa da deliberação. Ele fica ali apertando o botão do sim, não, abstenção, porque o líder diz no microfone a posição do partido e o deputado vota.

Mas há também aqueles que defendem a atuação do Colégio de Líderes, reconhecendo os benefícios que o órgão proporciona ao funcionamento do Congresso Nacional.

Soares (1993), por exemplo, acredita que o Colégio de Líderes, como reflexo natural de uma nova forma de organização da sociedade civil após o regime militar, inaugurou um sistema decisório mais ágil e coeso na Câmara dos Deputados. Ao se reunirem com o Presidente da Casa e promoverem negociações acerca dos projetos mais importantes, os líderes assumem responsabilidades que garantem maior celeridade às votações, sendo certo que isso se dá sob o olhar vigilante da imprensa e da própria sociedade.

José Genoino, que exerceu diversos mandatos de Deputado Federal e participou do processo de formalização do Colégio de Líderes no Regimento Interno da Câmara, atribui a centralização de poderes na Mesa e no colegiado ao fato de muitos dos deputados eleitos não acompanharem a dinâmica do Plenário e das comissões. Para ele, os legisladores estão sempre prontos para votar, mas também sempre à espera da pauta e da orientação do seu líder, ficando, por decisão própria, à margem do processo legislativo. Por essa razão, as lideranças partidárias passariam a centralizar no colegiado as decisões quanto às matérias mais relevantes (GENOINO, 1994).

O cientista político Fernando Limongi manifestou preocupação quando se debatia uma possível extinção do Colégio de Líderes. Ele lembrou que há sempre uma tendência ao fortalecimento do sistema partidário e, ao mesmo tempo, uma tentativa de objurgar o colegiado, o que lhe parece uma contradição. Primeiramente, seria necessário definir quem tomaria para si as atribuições daquele órgão e de que forma seriam tomadas as decisões (VIANA, 1994).

Carlos Alberto Novaes se une à corrente contrária à extinção do Colégio de Líderes. O pesquisador salienta que o Plenário, sozinho, não teria organização suficiente para conduzir o processo decisório. Aduz ainda que, se fosse retirada dos líderes essa prerrogativa, outro órgão interno da Câmara seria responsável por isso. Sob o seu ponto de vista, o ideal seria a criação de mecanismos novos que configurassem os líderes como efetivos representantes de suas bancadas (NOVAES, 1994).

Ao controlar a agenda política da Casa, o Colégio de Líderes limita a autonomia e a efetiva participação dos demais parlamentares no processo de elaboração das leis. Por outro lado, permite uma coesão interna dos partidos e mantém linearidade na execução dos projetos de governo. Além disso, apesar do prejuízo à representatividade, deve-se questionar se seria necessário - ou melhor, se seria desejável - que os projetos aprovados pelo Legislativo refletissem sempre a vontade da maioria dos parlamentares. 
A esse respeito, Jobim (2011) destaca que a operacionalidade de um Parlamento é tanto maior quanto menor é a sua representatividade. Um alto índice de representatividade gera um baixo índice de homogeneidade dentro da assembleia, o que prejudica o processo decisório. Um parlamento bastante representativo e heterogêneo, ao apresentar capacidade decisória reduzida, termina por ser pouco produtivo, já que não permite ampla produção de maioria. O choque entre a necessidade de decidir e a não produção de maioria acaba levando à ambiguidade dos textos legais, já que esse é um dos mecanismos que permite a aprovação de leis em ambientes tão heterogêneos. E daí surge o mal da transferência, ao Poder Judiciário, de um poder legislativo supletivo.

Durante pouco mais de vinte anos, já foram apontadas diversas saídas para amenizar os danos causados à representatividade parlamentar em razão da excessiva concentração de poderes no Colégio de Líderes.

Para alguns, como José Genoino e Carlos Alberto Novaes (VIANA, 1994; NOVAES, 1994), o melhor seria uma reforma institucional cautelosa e criteriosa que introduzisse no Regimento Interno o disciplinamento não só das reuniões de liderança, mas também das reuniões de bancada. Os demais parlamentares teriam mais voz e influência sobre o seu líder, participando indireta, porém mais ativamente, das deliberações do Colégio de Líderes.

Ocorre que as diretrizes para o funcionamento das bancadas parlamentares, como a definição da periodicidade com que se reúnem os seus integrantes, constituem assunto interna corporis, alheio à competência do Regimento Interno. A matéria é regulada pelos partidos políticos, que, pelo $\S 1^{\circ}$ do art. 17 da Carta de 1988, receberam autonomia constitucional para definir sua estrutura interna, sua organização e seu funcionamento (BRASIL, 1988). Aliás, a solução apontada acima dificilmente encontraria amparo nas lideranças partidárias, em razão da já conhecida resistência das siglas a mecanismos externos de controle de sua estrutura e de seus procedimentos.

Outras soluções são propostas, como a apresentada por Jobim (1994). Ele considera improvável a abertura do processo legislativo para a massa dos parlamentares, principalmente em função das corporações em atividade no Congresso. O ex-Deputado indica, portanto, como possível resposta ao impasse no processo decisório do Legislativo, uma nova organização da pauta, com maiores prazos entre a divulgação das proposições e a sua apreciação e com maior observância à agenda publicada antecipadamente. Esse mecanismo obrigaria os líderes a promover discussões internas nas bancadas a respeito dos temas constantes do cronograma, de forma que, quando chegasse o momento das negociações no Colégio de Líderes, a vontade dos liderados estivesse ali efetivamente representada.

De qualquer modo, as propostas apresentadas apontam sempre para dois caminhos: a regulação do funcionamento das bancadas pelo Regimento Interno e (ou) a democratização da 
Ordem do Dia. Na verdade, a segunda proposta, ao elevar a transparência, a previsibilidade e a capacidade informacional do parlamentar, busca também alterar as relações entre o líder e o restante da bancada, através do favorecimento do debate.

A obrigatoriedade de um cronograma de votações relativo às comissões e ao Plenário e uma pauta mensal organizada e transparente, divulgada ampla e antecipadamente, de modo a se conferir aplicação efetiva ao art. 17, inciso I, alínea $s$, do Regimento Interno, estimularia uma maior participação dos deputados e não traria malefícios ao desenvolvimento do processo legislativo. Infelizmente, porém, as prioridades no jogo político se transformam em velocidade tal que qualquer pauta que pretenda se concretizar em um período de 30 dias ou mais resta inviabilizada. Além disso, alterações institucionais como essa não despertam o interesse dos líderes e nem do Presidente da Casa, atores que estão mais preocupados em conservar o controle concentrado da pauta e, consequentemente, do próprio Parlamento.

A observância de uma pauta mensal dificultaria o trabalho do líder junto à sua bancada, já que a ele seria imposto o ônus de convocar os deputados para debater assuntos constantes da pauta. Além disso, ao ampliar o nível de discussão, um cronograma mensal faria desaparecer característica fundamental do poder do líder, atributo que hoje se assemelha ao voto de liderança do regime militar: a força ligada à imprevisibilidade da pauta, que garante ao líder o poder de imposição de sua orientação. É mais cômodo e adequado às lideranças que se dê continuidade à dinâmica atual, em que boa parte dos parlamentares é surpreendida em Plenário e acaba votando de acordo com o encaminhamento de seu líder.

Mozart Vianna de Paiva, que exerceu o cargo de Secretário-Geral da Mesa da Câmara entre 1991 e 2011, oferece uma proposta mais factível: a extinção da votação simbólica para os requerimentos previstos pelo art. 155 do Regimento Interno. Para ele (PAIVA, 2011), a imposição da votação nominal para todos os requerimentos de "urgência urgentíssima" permitiria que a totalidade dos deputados fosse chamada ao processo de votação. Assim, todos seriam forçados a se manifestar acerca da matéria, e o argumento de diversos parlamentares no sentido de se sentirem excluídos das decisões mais relevantes seria afastado, pelo menos quanto a esse tipo de votação.

$\mathrm{Na}$ verdade, ainda não se implementou reforma regimental que apresente, em sua essência, método alternativo ao Colégio de Líderes. De fato, alguns mecanismos poderiam ser adotados com o intuito de reduzir o poder das lideranças e favorecer a participação dos demais deputados no processo legislativo. Exemplo disso seria o fortalecimento das comissões temáticas, com a extensão do período de mandato de seus membros e o estabelecimento de normas que impusessem maior equidade na distribuição das relatorias.

Desde que a Constituição de 1988 delegou às comissões do Congresso Nacional e de suas Casas capacidade deliberativa para discutir e votar conclusivamente projetos de lei, vem se 
observando um intenso trabalho legislativo desses órgãos fracionários, que apresentam produção relevante não apenas em termos numéricos, mas também no campo temático. Matérias importantes, de interesse tanto do Poder Executivo quanto do Poder Legislativo, têm sido apreciadas pelas comissões da Câmara dos Deputados mediante seu poder conclusivo, o que colabora para a descentralização dos trabalhos legislativos no Parlamento brasileiro (AMARAL, 2009).

Medidas que favoreçam cada vez mais a especialização das comissões contribuem também para o seu fortalecimento e, consequentemente, para uma participação maior e mais qualificada dos legisladores no processo normativo. Por isso, é necessário implementar alterações regimentais que dilatem o período de mandato dos presidentes e vice-presidentes das comissões temáticas - que hoje equivale a um ano - , assim como seria importante conceder mandatos fixos aos seus integrantes. Tais mecanismos permitiriam um andamento mais ágil dos trabalhos e confeririam aos deputados uma atuação mais estável e independente em relação a seus líderes, que perderiam a prerrogativa de substituir seus liderados nas comissões a qualquer tempo.

Aliadas a isso, regras que determinem uma distribuição mais igualitária das relatorias no âmbito das comissões, hoje operada a critério de seus presidentes e com considerável interferência das lideranças partidárias, também colaborariam para a descentralização do poder decisório. No panorama atual, um deputado pode vir a relatar dezenas de proposições durante uma legislatura, a depender do partido ao qual pertença e (ou) da credibilidade de que disponha perante seus pares, enquanto outros recebem - quando recebem - apenas um ou dois projetos para proferir parecer no mesmo período (AMARAL, 2009).

Enquanto a reforma não vem, é salutar que os parlamentares passem a apreciar com maior afinco até mesmo aquelas matérias que não suscitam, em particular, o interesse do seu Estado ou do seu eleitorado. Além disso, cabe ao legislador conversar com seu líder, insistir para que sua demanda seja atendida, usando os meios que considerar necessários e suficientes para atingir esse objetivo. Entre ações brandas e extremadas, o parlamentar deve escolher aquela que mais lhe pareça conveniente às suas necessidades, utilizando-a como objeto de pressão sobre o líder de seu partido.

\subsection{Estrutura, funcionamento e atribuições}

As representações partidárias e os blocos parlamentares compõem a estrutura da Câmara dos Deputados. Aos que agrupam ao menos um centésimo da composição da Casa é garantida a prerrogativa da escolha de um líder. A decisão, adotada no início da legislatura ou a partir da criação de um bloco parlamentar, deve ser encaminhada à Mesa com a assinatura da maioria absoluta dos integrantes da representação ou do bloco. Registre-se que o Governo 
também é representado por um líder e por cinco vice-líderes, todos indicados e destituídos por decisão do Presidente da República.

Os líderes da Maioria, da Minoria, dos partidos, dos blocos parlamentares e do Governo constituem o Colégio de Líderes, instituto que consagrou a liderança parlamentar em nosso processo decisório legislativo.

No primeiro biênio após a sua institucionalização (1989 a 1991), quando a Presidência era exercida pelo Deputado Paes de Andrade, as reuniões do colegiado eram conduzidas pelo líder do maior partido da Casa à época, o PMDB. Mas, a partir de 1991, a convocação do órgão já dependia de determinação do Presidente da Câmara, que passou a coordenar esses encontros (VIEIRA, 2009).

Aos líderes da Maioria, da Minoria, do Governo e de partidos que compõem bloco parlamentar é franqueado o direito a voz, mas não a voto, porque os integrantes dessas representações já têm suas posições defendidas pelos demais líderes nas reuniões do colegiado. As decisões são, sempre que possível, tomadas pelo consenso entre seus membros. Não havendo acordo, determina o Regimento Interno que o resultado das deliberações acompanhe o critério da maioria absoluta, ponderando-se os votos dos líderes de acordo com a expressão numérica de suas bancadas.

O consenso é sempre perseguido, mas a regra majoritária, amplamente criticada pelos integrantes de partidos menores durante o processo de formalização do Colégio de Líderes, é letra morta do Regimento Interno. Vianna (2011) afirma que, durante os 20 anos em que secretariou as reuniões de líderes, viu pouquíssimas tentativas, sem sucesso, de utilização desse mecanismo. Na prática, as matérias são discutidas e os líderes se manifestam, defendem sua posição, oferecem sugestões e fazem cobranças ao Presidente, mas, não havendo acordo, a decisão sobre o impasse fica suspensa ou é entregue à análise do Plenário.

Como não existem regras regimentalmente definidas acerca da elaboração da pauta, quando o Presidente decide enviar a votação matéria cuja inclusão na Ordem do Dia não obteve consenso entre os líderes, cabe a eles, a partir daí, conforme os interesses políticos de sua sigla, conduzir negociações e manobras regimentais em Plenário para tentar construir acordos sem suscitar conflitos com os membros de sua bancada.

O Presidente, no entanto, é o ator mais interessado no alcance do consenso nas reuniões, já que seu conceito perante a opinião pública fica tão melhor quanto maior é o número de proposições aprovadas em menor espaço de tempo. Matérias levadas a votação em Plenário sem acordo prévio entre as lideranças tendem a procrastinar o andamento das sessões, transmitindo uma falsa percepção de lentidão do Legislativo, conceito que geralmente é atribuído, em parte, a uma suposta ineficiência na condução do processo por parte do Presidente da Câmara. 
O Colégio de Líderes é convocado de acordo com a necessidade dos trabalhos legislativos e o perfil do Presidente da Casa. Luís Eduardo Magalhães, por exemplo, não convocou nenhuma reunião de líderes durante os dois anos em que presidiu a Câmara, de 1995 a 1997. Já no biênio seguinte, no qual Michel Temer ocupou a Presidência, foram realizadas 55 reuniões (VIEIRA, 2009).

Ao Presidente da Câmara cabe, ouvido o Colégio de Líderes, elaborar a agenda de proposições que deverão ser apreciadas no mês subsequente. O colegiado, portanto, atua como um fórum orientador das discussões, sendo certo que a atuação do Presidente como coordenador das reuniões permite concluir que é sua a palavra final, conforme a autonomia a ele conferida pelo Regimento Interno (VIEIRA, 2009). Contudo, quando os líderes estabelecem consenso em relação a determinada matéria e solicitam a sua inclusão na Ordem do Dia, dificilmente a oposição exclusiva do Presidente se sobrepõe à vontade unânime das lideranças.

As reuniões do Colégio de Líderes se realizam, como regra, no gabinete da Presidência da Câmara, mas, em diversas ocasiões, os encontros são marcados na residência oficial do Presidente da Casa, na Península dos Ministros. Isso ocorre quando há temas sensíveis, cuja discussão mereça a convocação de reuniões restritas, ou por simples ato de delicadeza, de deferência, para que aos líderes seja oferecido mais conforto ao se reunirem com o Presidente.

As reuniões do colegiado não são abertas ao público e à imprensa. A elas comparecem, além dos líderes e do Presidente da Casa, qualquer parlamentar com interesse nas deliberações e os assessores das lideranças dos partidos. A participação da assessoria nesses encontros é fundamental para o desenvolvimento do processo legislativo, já que os funcionários devem estar a par de toda e qualquer negociação entre os líderes para melhor orientar os trabalhos em Plenário.

Mas a atuação do Colégio de Líderes não se restringe às reuniões formais, em geral realizadas semanalmente. $\mathrm{O}$ colegiado funciona também nos eventos e encontros informais em que os líderes discutem estratégias e promovem negociações. Além disso, os acordos - e também os desacordos - muitas vezes são estabelecidos em Plenário, no calor das discussões. Tudo isso faz parte do funcionamento do órgão.

O poder dos líderes se manifesta de variadas formas. Em primeiro lugar, são eles, em conjunto com o Presidente da Câmara dos Deputados, que determinam a pauta da Ordem do Dia das sessões plenárias e regulam o funcionamento das comissões. São também os líderes que aproximam os deputados e as diversas autoridades do Poder Executivo. Ademais, a utilização de mecanismos como a votação simbólica e os requerimentos de urgência dá o tom da influência das lideranças partidárias sobre o processo legislativo federal.

Os requerimentos de urgência, especialmente a "urgência urgentíssima", embora sejam prerrogativas concedidas aos líderes individualmente, abrigam concessões que se realizam sob a 
égide do colegiado. Quando um parlamentar se interessa por determinado projeto, ele recorre ao seu líder, que negocia com outras lideranças a inclusão da proposição na pauta do Plenário através da aprovação de um pedido de urgência. Esse tipo de barganha, cujo resultado satisfatório depende de transações promovidas entre líderes, sustenta as relações de liderança e, em associação com outros fatores, justifica a transferência de poderes individuais dos deputados para seus líderes.

Apesar de prevista pelo Regimento Interno como recurso excepcional para cuidar de temas relevantes e urgentes, a "urgência urgentíssima", prevista no art. 155 do Regimento Interno e normalmente decidida durante as reuniões do Colégio de Líderes, passou a ser deliberadamente utilizada. Ela permite uma aprovação mais ágil dos projetos de lei, inclusive das propostas originárias do Poder Executivo, fazendo com que a agenda do Governo seja efetiva e mais rapidamente aprovada.

O pedido de verificação de votação é também um recurso dos líderes em Plenário para forçar a votação simbólica de determinada matéria, evitando uma possível derrota pela votação nominal. É que o Regimento Interno determina não ser possível novo pedido de verificação antes de decorrida uma hora do anterior, salvo pela aprovação de requerimento apresentado por um décimo dos membros da Casa ou por líderes que representem esse número. Então, no prazo de uma hora, solicita-se votação nominal sobre matéria menos importante para que, quanto a projeto cuja aprovação interesse aos líderes, torne-se obrigatória a votação simbólica (NOVAES, 1994).

Por fim, registre-se a comparação, no quadro abaixo, entre as prerrogativas individuais conferidas aos líderes e os poderes específicos garantidos ao Colégio de Líderes pelo Regimento Interno:

\section{Quadro n' 1 - Prerrogativas individuais e colegiadas atribuídas aos líderes (Quadro elaborado pela autora)}

\begin{tabular}{|c|c|c|}
\hline PRERROGATIVAS & $\begin{array}{c}\text { COLÉGIO DE } \\
\text { LÍDERES }\end{array}$ & LÍDER \\
\hline $\begin{array}{c}\text { Incluir proposição pela dispensa de } \\
\text { interstício, } \\
\text { com a distribuição de avulsos (art. 150, } \\
\text { parágrafo único) }\end{array}$ & Imediato & - \\
\hline $\begin{array}{c}\text { Incluir em pauta proposição urgente } \\
\text { (art.154, II) }\end{array}$ & - & $\begin{array}{c}\text { Requerimento, ao plenário, de } \\
\text { líderes que representem 1/3 dos } \\
\text { membros da Casa }\end{array}$ \\
\hline $\begin{array}{c}\text { Incluir em pauta proposição que trate de } \\
\text { relevante e inadiável interesse nacional } \\
\text { ("urgência urgentíssima" - art. 155) }\end{array}$ & - & $\begin{array}{c}\text { Requerimento, ao plenário, de } \\
\text { líderes que representem maioria } \\
\text { absoluta dos membros da Casa }\end{array}$ \\
\hline \multicolumn{2}{c}{} \\
\hline
\end{tabular}




\begin{tabular}{|c|c|c|}
\hline PRERROGATIVAS & $\begin{array}{l}\text { COLÉGIO DE } \\
\text { LÍDERES }\end{array}$ & LÍDER \\
\hline $\begin{array}{l}\text { Alterar a ordem de discussão ou votação de } \\
\text { proposição sobre as do mesmo grupo (art. } \\
160)\end{array}$ & $\begin{array}{l}\text { Requerimento } \\
\text { à Mesa }\end{array}$ & - \\
\hline $\begin{array}{c}\text { Adiar votação de proposição por até } 5 \\
\text { sessões (art. 193) }\end{array}$ & - & Requerimento ao plenário \\
\hline $\begin{array}{l}\text { Adiar, por até } 2 \text { sessões, votação de } \\
\text { proposição em tramitação urgente (art. 193, } \\
\left.\qquad 3^{\circ}\right)\end{array}$ & - & $\begin{array}{l}\text { Requerimento, ao plenário, de } \\
\text { líderes que representem } 1 / 10 \\
\text { dos membros da Casa }\end{array}$ \\
\hline $\begin{array}{l}\text { Destacar parte de proposição para votação } \\
\text { em separado (art. 161, I) }\end{array}$ & - & $\begin{array}{l}\text { Requerimento, ao plenário, de } \\
\text { líderes que representem } 1 / 10 \\
\text { dos membros da Casa }\end{array}$ \\
\hline $\begin{array}{l}\text { Dispensar discussão de proposição com } \\
\text { todos os pareceres favoráveis (art. 167) }\end{array}$ & - & $\begin{array}{l}\text { Requerimento de líder ao } \\
\text { plenário }\end{array}$ \\
\hline Encerrar discussão (art. $178, \S 2^{\circ}$ ) & - & $\begin{array}{l}\text { Requerimento, ao plenário, de } \\
\text { líderes que representem 5/100 } \\
\text { dos membros da Casa }\end{array}$ \\
\hline $\begin{array}{l}\text { Submeter matéria a votação nominal (art. } \\
\left.\qquad 185, \S 3^{\circ}\right)\end{array}$ & - & $\begin{array}{l}\text { Requerimento, ao plenário, de } \\
\text { líderes que representem } 6 / 100 \\
\text { dos membros da Casa }\end{array}$ \\
\hline $\begin{array}{l}\text { Solicitar verificação de votação antes do } \\
\text { decurso de } 1 \text { hora da última (art. } 185, \S 4^{\circ} \text { ) }\end{array}$ & - & $\begin{array}{l}\text { Requerimento, ao plenário, de } \\
\text { líderes que representem } 1 / 10 \\
\text { dos membros da Casa }\end{array}$ \\
\hline $\begin{array}{l}\text { Submeter matéria a votação secreta (art. } \\
\qquad 188, \mathrm{II})\end{array}$ & - & $\begin{array}{l}\text { Requerimento, ao plenário, de } \\
\text { líderes que representem } 1 / 10 \\
\text { dos membros da Casa }\end{array}$ \\
\hline $\begin{array}{l}\text { Submeter a votação matéria não emendada } \\
\text { no segundo turno (art. } 149, \text { II) }\end{array}$ & - & $\begin{array}{l}\text { Requerimento de líder ao } \\
\text { plenário }\end{array}$ \\
\hline Convocar sessão secreta (art. 92, I e II) & Imediato & $\begin{array}{l}\text { Requerimento de líder ao } \\
\text { plenário }\end{array}$ \\
\hline Convocar sessão solene (art. 68) & - & $\begin{array}{l}\text { Requerimento, ao plenário, de } \\
\text { líderes que representem } 1 / 10 \\
\text { dos membros da Casa }\end{array}$ \\
\hline $\begin{array}{l}\text { Convocar sessão extraordinária e prorrogar } \\
\text { prazo de sessão ordinária e de Ordem do } \\
\text { Dia (art. } 67, \S 1^{\circ} \text {, art. } 72 \text { e art. } 84 \text { ) }\end{array}$ & Imediato & - \\
\hline $\begin{array}{l}\text { Convocar sessão extraordinária para } \\
\text { discussão e votação de matérias constantes } \\
\left.\text { do ato de convocação (art. } 66, \S 4^{\circ}\right)\end{array}$ & Imediato & - \\
\hline Criar Comissão Especial (art. 34, II) & - & $\begin{array}{l}\text { Requerimento de líder ao } \\
\text { Presidente da Casa }\end{array}$ \\
\hline $\begin{array}{l}\text { Transformar sessão ordinária em Comissão } \\
\text { Geral (art. 91, I) }\end{array}$ & $\begin{array}{l}\text { Requerimento ao } \\
\text { Presidente }\end{array}$ & - \\
\hline
\end{tabular}

Fonte: BRASIL. Câmara dos Deputados (1989). 


\section{A atuação do Colégio de Líderes durante o primeiro período da sessão legislativa ordinária de 2009: expectativas, prioridades e resultados}

Para demonstrar a influência dos líderes partidários e a efetividade das decisões do Colégio de Líderes sobre a agenda legislativa da Câmara dos Deputados, foram analisados os registros disponíveis na Secretaria-Geral da Mesa acerca das reuniões do colegiado ocorridas durante o primeiro semestre de 2009, bem como as notícias da Agência Câmara divulgadas no mesmo período. Tal estudo tem como objetivo ilustrar a atuação das lideranças, esclarecendo de que modo o Colégio de Líderes participou da elaboração da pauta da Ordem do Dia e investigando se as votações em Plenário foram, de fato, orientadas pelos acordos celebrados naquelas reuniões.

Cumpre ressaltar, inicialmente, que as conclusões aqui expostas se basearam apenas no primeiro semestre de 2009, quando a Câmara dos Deputados era presidida pelo então Deputado Michel Temer, e, portanto, se prestam a apresentar ponderações acerca da atuação dos líderes apenas durante aquele período. Conclusões mais amplas demandariam um estudo mais aprofundado sobre todas as legislaturas posteriores à institucionalização do Colégio de Líderes, até porque cada Presidente vem adotando um modo particular de conduzir as reuniões do colegiado e de facultar a participação dos líderes.

Quanto ao período analisado, há duas razões principais para a sua escolha. A primeira diz respeito ao fato de o Presidente Michel Temer sempre ter se destacado por permitir ampla participação dos líderes partidários no processo decisório, o que possibilita uma análise mais completa da atuação das lideranças em período mais curto. A segunda está associada à decisão de Temer, em março de 2009, no sentido de que as medidas provisórias somente passariam a sobrestar a pauta com relação a leis ordinárias, entendimento que se caracterizou como um divisor de águas para as votações no Plenário da Casa.

Em fevereiro de 2009, a Agência Câmara divulgou entrevistas com os líderes de quase todos os partidos com representação na Casa, momento em que cada um declarou as matérias consideradas prioritárias pelo seu partido para discussão no primeiro semestre daquele ano. Os principais pleitos, mencionados por quase todos os líderes entrevistados, eram:

$\checkmark$ destrancamento da pauta, por meio da aprovação da PEC das Medidas Provisórias(511/2006);

$\checkmark$ reforma política (PL 5498/2009);

$\checkmark$ reforma tributária (PEC 233/2008);

$\checkmark$ PEC dos Vereadores (333/2004); e

$\checkmark$ enfrentamento da crise financeira. 
O Presidente da Casa, em manifesto apoio aos líderes, promoveu o debate desses cinco temas, conseguindo solucionar, total ou parcialmente, quatro deles. Daí já se observa, mesmo inicialmente, o constante entendimento buscado entre Presidente e líderes partidários.

A partir do estudo realizado, foi possível concluir que, nas reuniões destinadas à elaboração da pauta, o Presidente sempre dispunha de uma lista inicial com suas sugestões, que depois vinham a ser submetidas à apreciação dos líderes. E eles acabavam se posicionando contra ou a favor dos assuntos apontados pelo Presidente, mas também eram incentivados a oferecer sugestões, o que de fato ocorria. Contudo, tantas eram as propostas levadas por cada um dos líderes que se tornava impossível para o Presidente atender a todos. Quando a reunião se encerrava, o resultado, em geral, era uma pauta composta pelas sugestões iniciais levadas pelo Presidente, além de alguns projetos solicitados pelos líderes.

A tendência costuma ser, portanto, a de os líderes negociarem os pontos nos quais se baseia a pauta inicialmente proposta pelo Presidente. O Colégio de Líderes acaba atuando, quanto à elaboração da pauta da Ordem do Dia das sessões plenárias, exatamente conforme prevê o Regimento Interno: ele apenas é ouvido pelo Presidente, que é efetivamente o responsável por elaborar a pauta.

Tanto é assim que, no período analisado, de todas as proposições discutidas em Plenário, entre medidas provisórias, projetos de lei, projetos de lei complementar, projetos de resolução e propostas de emenda à Constituição, o Presidente não se opôs a nenhuma delas; pelo contrário, a maioria havia sido sugerida por ele ou já tinha recebido o seu apoio manifesto durante as reuniões. Os diversos pleitos dos líderes, por sua vez, ora foram atendidos, ora não, a depender do interesse do Presidente, sem que se tenha observado favorecimento a qualquer partido.

\section{Proposições analisadas pelo Plenário da Câmara dos Deputados (exceto projetos de decreto legislativo)}

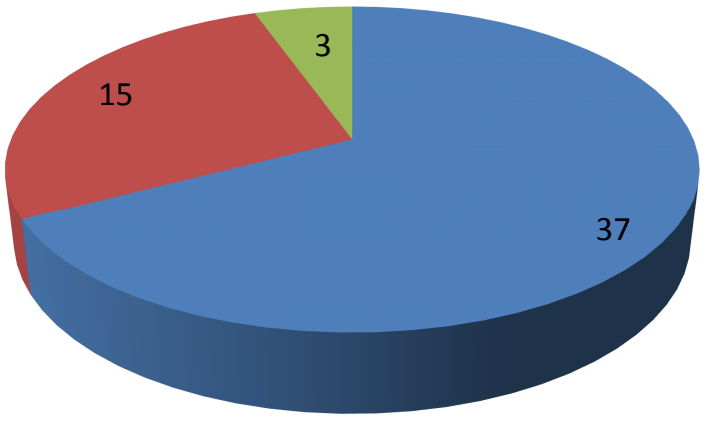
Matérias encaminhadas à análise do Plenário após proposta do Presidente da Câmara dos Deputados ao Colégio de Líderes - Matérias encaminhadas à análise do Plenário após proposta dos Líderes partidários ao Presidente da Câmara dos Deputados Matérias apreciadas em Plenário não discutidas anteriormente pelo Colégio de Líderes


Figura 1: Gráfico representativo das matérias apreciadas pelo Plenário da Câmara dos Deputados durante o primeiro período da Sessão Legislativa Ordinária de 2009, excluídos os projetos de decreto legislativo.

Também se pôde confirmar, conforme demonstrado pela tabela abaixo, que o Presidente Michel Temer de fato franqueava a palavra a todos os líderes, e, considerando-se a expressão numérica de cada bancada, havia relativo equilíbrio entre eles no que se refere às suas manifestações durante as reuniões. Como esperado, a maioria dos partidos denominados "nanicos" pouco apareceu nos registros, enquanto as legendas mais numerosas se manifestaram com frequência nos encontros. Nesse ponto, merece destaque a liderança do PSOL, que, apesar de contar com apenas 3 parlamentares, fez mais reivindicações que os líderes do PMDB detentor da maior bancada à época, abrangendo 89 deputados — e do Governo.

Quadro n 2 - Manifestação das lideranças de partidos, blocos e representações nas reuniões do Colégio de Líderes

\begin{tabular}{|c|c|c|}
\hline $\begin{array}{l}\text { PARTIDO, BLOCO OU } \\
\text { REPRESENTAÇÃO }\end{array}$ & $\begin{array}{l}\text { NÚMERO DE PARLAMENTARES } \\
\text { REPRESENTADOS }\end{array}$ & $\begin{array}{c}\text { MANIFESTAÇÕES } \\
\text { NO COLÉGIO DE } \\
\text { LÍDERES }\end{array}$ \\
\hline PSDB & 66 & 12 \\
\hline $\mathrm{PT}$ & 83 & 12 \\
\hline DEM & 65 & 10 \\
\hline PR & 25 & 10 \\
\hline PSOL & 3 & 10 \\
\hline Governo & - & 9 \\
\hline PDT & 24 & 9 \\
\hline PPS & 22 & 9 \\
\hline PCdoB & 13 & 7 \\
\hline PMDB & 89 & 7 \\
\hline PP & 41 & 7 \\
\hline PSB & 27 & 7 \\
\hline PTB & 22 & 6 \\
\hline PV & 13 & 6 \\
\hline $\begin{array}{c}\text { Bloco } \\
\text { PSB/PCdoB/PMN/PRB }\end{array}$ & 44 & 5 \\
\hline Bancada Feminina & 43 & 4 \\
\hline PMN & 3 & 1 \\
\hline PSC & 9 & 1 \\
\hline PTC & 3 & 1 \\
\hline
\end{tabular}

Fontes: Banco de dados da autora produzido com base em informações disponibilizadas pela SecretariaGeral da Mesa da Câmara dos Deputados; dados disponíveis em http://www2.camara.gov.br/deputados/liderancas-e-bancadas/bancada-na-eleicao. 
Como se vê, não foi confirmada nesta pesquisa a assertiva de alguns autores, como Novaes (1994), no sentido de que no Colégio de Líderes as lideranças de partidos maiores, por sentirem maior dificuldade em controlar a totalidade de suas bancadas e arregimentar seus liderados nas votações nominais, se sentem acuadas pelos líderes dos partidos minoritários. Além disso, os dados disponíveis não confirmam o argumento de que as menores legendas, por serem mais numerosas, acabam exercendo poder de influência bem superior ao que lhes caberia caso seus votos fossem ponderados de acordo com a expressão numérica de suas bancadas.

Também chamou a atenção o modo como se manifestaram os partidos de oposição, cada um à sua maneira. O PSDB costumava apresentar inúmeras sugestões de proposições para inclusão em pauta; o PPS solicitava reiteradamente a formulação de uma pauta ampla e definida para as votações; e o DEM era o que mais se insurgia contra as propostas apresentadas pelas demais agremiações.

Convém registrar que, dos quatro projetos prioritários apresentados pelo DEM (PL 5498/2009, que promoveu a reforma eleitoral; PL 3514/2008, que tratava da rastreabilidade das carnes bovina e bubalina; PL 1472/2007, que dispunha sobre direitos do consumidor; PLP $12 / 2003$, que fixava normas a serem cumpridas pelos entes federados para a preservação do meio ambiente), três foram votados e aprovados no período estudado, enquanto o líder do Governo não foi atendido em nenhum de seus cinco pedidos específicos (PL 3021/2008, que dispunha sobre filantropia; PL 1664/2007, que tratava dos direitos dos estrangeiros; PL 1746/2007, que criava cargos no MEC; PRC 47/2007, que dava poderes conclusivos às comissões permanentes para a aprovação de acordos internacionais; PLP 92/2007, sobre as fundações públicas).

Talvez isso tenha acontecido porque a pauta do Presidente costumava coincidir com as prioridades do Governo, tanto que o Líder Henrique Fontana, não raras vezes, demonstrou apoiou explícito às decisões de Michel Temer nas reuniões. Mas isso pode demonstrar também que, na verdade, o Presidente busca o alcance do consenso, e não um constante favorecimento à pauta do Executivo, como alguns autores costumam defender.

O que fica realmente claro é o domínio do Presidente sobre a elaboração da pauta da Ordem do Dia. Por outro lado, é notório também que os líderes devem manter em Plenário os acordos realizados nas reuniões do colegiado ou, então, promover novas negociações para que as proposições sejam discutidas e finalmente votadas. E é neste ponto, no desenrolar da sessão, que se observa o maior poder das lideranças.

No período estudado houve casos de sobreposição do poder dos líderes à decisão do Presidente da Casa. No dia 13 de maio de 2009, por exemplo, os líderes retiraram de pauta o PL 836/03, que criava o cadastro positivo de consumidores e cuja inclusão na pauta da Ordem do Dia vinha sendo reiteradamente defendida por Michel Temer nas reuniões. A decisão dos líderes 
partiu do fato de o Presidente ter tentado votar a proposição na mesma sessão em que se apreciava a MPV 458/2009, mas o acordo anterior entre os líderes era de que o projeto de lei só seria discutido em sessão extraordinária convocada exclusivamente para esse fim. Em outro momento, no dia 14 de julho, após tentar, sem sucesso, promover um consenso entre os líderes acerca da votação da MPV 460/2009, o Presidente forçou a apreciação da medida e decidiu que ela deveria ser discutida na sessão seguinte. No Plenário, contudo, sem acordo entre os líderes, a matéria foi retirada de pauta.

Essa relação simbiótica entre Presidente e líderes partidários indica que o primeiro administra a tramitação das matérias e é o responsável direto pela elaboração da pauta de votações, enquanto os líderes exercem extrema influência sobre os procedimentos em Plenário. $\mathrm{O}$ poder de agenda é compartilhado entre esses atores porque nem o Presidente consegue implementar suas prioridades sem a concordância de boa parte dos líderes e nem os líderes alcançam seus objetivos sem a anuência do Presidente.

O Presidente e os líderes definem, nas reuniões, o que será discutido durante a Ordem do Dia, mas também negociam o mérito das matérias pautadas. Observe-se que o resultado da votação de todas as proposições que tiveram sua tramitação concluída em Plenário durante o período analisado coincidiu com a decisão acertada anteriormente nas reuniões do Colégio de Líderes. A Medida Provisória das Filantrópicas (MPV 446/2008), por exemplo, foi a única matéria rejeitada em Plenário, e isso ocorreu por decisão dos líderes após sugestão do Presidente, já que a intenção era pautar, posteriormente, o PL 3021/2008 para disciplinar a matéria, que não havia sido considerada relevante ou urgente pelo Relator da medida provisória.

A respeito das negociações no âmbito do Colégio de Líderes, Teixeira (2011) argumenta que, antes da institucionalização, havia apenas acordo de procedimentos, sendo bem menor o número de deputados que não estavam no Plenário desde o início dos debates e que chegavam perguntando como deveriam votar. Mas, com o passar do tempo, os líderes passaram a negociar também o mérito das matérias, e, em sua opinião, foi esse o fator primordial para a quebra de um ambiente de debate muito proveitoso que havia no Plenário. Nas palavras do Deputado: "o combate em Plenário perdia o sentido. Foi aumentando esse número dos (deputados) que perguntavam como é que se vota".

A pesquisa realizada permitiu a observação do que se propunha inicialmente: entender como se manifestam as lideranças nas reuniões com o Presidente e verificar se as decisões tomadas no Colégio de Líderes de fato orientam as votações em Plenário, possibilidade que se confirmou.

Quanto à última conclusão, os dados registrados mostram que, de todas as proposições votadas nas sessões plenárias, apenas as seguintes não passaram pelo crivo do colegiado: o PL 4383/2008, que instituiu a Semana Nacional para Doação de Medula Óssea e foi aprovado em 
um gesto de solidariedade ao Deputado Beto Albuquerque, cujo filho havia falecido após lutar contra a leucemia; grande parte dos projetos de decreto legislativo sobre acordos internacionais, que em geral não suscitam controvérsias; o PRC 297/2006, que criou o Grupo Parlamentar Brasil-Suécia; e o PRC 27/2007, que instituiu o Prêmio Dr. Pinotti.

Como se vê, são poucos e incontroversos os projetos cuja discussão e aprovação em Plenário não foram definidas por deliberação prévia do Colégio de Líderes, o que demonstra a ampla concentração de poderes conduzida por esse órgão da Câmara dos Deputados.

\section{Conclusão}

As negociações entre lideranças são tão antigas quanto o próprio Parlamento brasileiro, mas o Colégio de Líderes, como órgão da Câmara dos Deputados, somente foi constituído em 1989, durante o processo de reforma do Regimento Interno da Casa. Essa institucionalização foi resultado da evidência alcançada pelos líderes partidários durante a Constituinte, já que os acordos entre lideranças foram os responsáveis pela celeridade e organização do processo de votação do projeto de Constituição.

A formalização das atividades do Colégio de Líderes acabou colaborando para a já existente centralização decisória no Congresso Nacional, que vem permitindo às lideranças conter o comportamento individualista dos deputados e garantir a disciplina entre os membros de sua bancada. Aliada a coalizões estáveis construídas pelo Presidente da República, essa centralização promove o controle parlamentar, evidenciado pelos elevados índices de congruência entre a orientação dos líderes e os votos de seus liderados.

Os poderes individuais dos legisladores restam inibidos pela frequente utilização, pelos líderes partidários, de suas prerrogativas regimentais, que incluem os mecanismos de verificação de votação, urgência e solicitação de votações nominais e de encerramento de debates. Por outro lado, é a atividade coordenada dos líderes que traz organização aos trabalhos legislativos, permitindo que estes se desenvolvam com qualidade e celeridade.

Para alguns, o sistema decisório anterior, pelo qual as lideranças negociavam entre si, discutiam as matérias com os membros de sua bancada e defendiam em Plenário a posição de seu partido, permitia maior participação dos deputados no processo decisório. Mas, para a maioria dos cientistas, a extinção do Colégio de Líderes somente transferiria para outro órgão da Casa a atribuição de colaborar para a organização da agenda legislativa, já que o Plenário não conseguiria preparar seus trabalhos sem o auxílio de um organismo responsável por selecionar e prever as discussões. Além disso, o Colégio de Líderes, apesar de limitar a participação da massa dos deputados, amplia a operacionalidade do Congresso, já que um parlamento é tão mais eficiente quanto menor é a sua representatividade (JOBIM, 2011). 
A abolição do Colégio de Líderes ou a reforma isolada de suas atribuições não surtiria bons efeitos em favor do processo legislativo e nem seria a solução para o problema da representatividade parlamentar; poderia, pelo contrário, ocasionar um andamento caótico do processo legislativo e provocar uma centralização de poderes ainda mais acentuada que a observada atualmente, mas nas mãos de órgão diverso dentro da estrutura da Casa. O que se faz relevante discutir, em futura e necessária reforma legislativa, são os limites a serem adotados para reduzir as mazelas causadas à representação parlamentar, mas a restrição ao poder concedido atualmente ao colegiado, sozinha, não solucionaria esse conflito.

Quanto ao funcionamento do Colégio de Líderes, impera a busca pelo consenso. Não havendo acordo, o Presidente decide não pautar a matéria ou, decidindo pautá-la, o impasse é transferido para o Plenário. Na verdade, o colegiado se caracteriza apenas como um grupo que orienta os debates parlamentares, já que a pauta é efetivamente definida pelo Presidente da Câmara.

A atuação do Colégio de Líderes não se limita, porém, às reuniões destinadas à elaboração da agenda legislativa. Muitas das decisões relevantes são tomadas em conjunto pelos líderes em Plenário, durante a discussão das proposições. Aliás, o êxito das votações depende diretamente da aquiescência dos líderes, conforme se pôde concluir pelo período analisado nesta pesquisa.

Também foi possível inferir que, durante as reuniões, não houve favorecimento a um ou outro partido, mas se percebeu que os partidos denominados "nanicos" pouco registraram suas reivindicações, enquanto líderes de maiores bancadas se manifestaram com mais frequência. $\mathrm{O}$ Governo também não foi favorecido durante o período estudado, mas não se sabe se isso ocorreu porque a pauta inicial do Presidente levada às reuniões já coincidia com a pauta do líder governista ou se realmente o Presidente não tinha interesse em favorecer o Executivo, mas, sim, em chegar ao consenso para possibilitar, no fim de seu mandato, estatísticas que demonstrassem aprovação substancial de proposições.

Por fim, a pesquisa alcançou um de seus objetivos específicos ao confirmar que as negociações levadas a efeito no âmbito do Colégio de Líderes de fato orientam as votações em Plenário. Observou-se que, de todas as matérias aprovadas no período, somente algumas poucas proposições que não suscitam controvérsia deixaram de passar pelo crivo do colegiado.

As conclusões deste artigo apenas complementam estudos anteriores que comprovam haver uma densa concentração decisória no Congresso Nacional, da qual o Colégio de Líderes é importante e poderoso colaborador. Entretanto, percebe-se que se torna cada vez mais trabalhoso implementar reformas institucionais que reduzam essa centralização, principalmente porque tais alterações não despertam o interesse dos atores que conduzem o processo legislativo federal. 


\section{Referências}

ABRANCHES, Sérgio Henrique H. Presidencialismo de coalizão: o dilema institucional brasileiro. DADOS - Revista de Ciências Sociais, Rio de Janeiro, v. 31, n. 1, p. 5-34, 1988.

AMARAL, Ana Regina Villar Peres. O Parlamento brasileiro - Processo, produção e organização legislativa: o papel das Comissões em perspectiva comparada. 2009. $180 \mathrm{f}$. Dissertação (Mestrado em Ciência Política) - Instituto de Pesquisas Universitárias do Rio de Janeiro e Centro de Formação, Treinamento e Aperfeiçoamento da Câmara dos Deputados, Rio de Janeiro, 2009.

AMES, Barry. Os entraves da democracia no Brasil. Rio de Janeiro: Editora FGV, $1^{\text {a }}$ ed., 2003.

BAAKLINI, Abdo I. O Congresso e o sistema político do Brasil. Rio de Janeiro: Paz e Terra, 1993.

BRASIL. Câmara dos Deputados. Resolução da Câmara dos Deputados n. 17, de 1989. Aprova o Regimento Interno da Câmara dos Deputados. Disponível em: $<$ http://www2.camara.gov.br/atividade-legislativa/legislacao/regimento-interno-da-camarados-deputados/ricdtextoatualizado>. Acesso em: 11out.2011.

BRASIL. Constituição (1988). Constituição da República Federativa do Brasil: texto constitucional promulgado em 5 de outubro de 1988, com as alterações adotadas pelas Emendas Constitucionais $\mathrm{n}^{\circ}$ s 1/1992 a 56/2007 e pelas Emendas Constitucionais de Revisão nº 1 a 6/1994. 26. ed. Brasília: Câmara dos Deputados, Coordenação de Publicações, 2008.

CINTRA, Antônio Octávio; LACOMBE, Marcelo Barroso. A Câmara dos Deputados na Nova República: a visão da Ciência Política. In: AVELAR, Lúcia; CINTRA, Antônio Octávio (Org.). Sistema Político Brasileiro: uma introdução. 2 ed. Rio de Janeiro: Konrad Adenauer-Stiftung. São Paulo: UNESP, 2007. p. 143-182.

FALCÃO, Alcino Pinto. Voto de liderança como "sub genus" do voto por procuração. Revista de Direito Constitucional e Ciência Política, Rio de Janeiro, n. 6, p. 236-256, jan.-jun. 1988.

FIGUEIREDO, Argelina Cheibub. Derrubando mitos (entrevista concedida a Angélica Santa Cruz). Veja, ed. 1378, ano 28, nº 6, p. 7-9, fev. 1995.

FIGUEIREDO, Argelina Cheibub; LIMONGI, Fernando. Mudança constitucional, desempenho do Legislativo e consolidação institucional. Revista Brasileira de Ciências Sociais, São Paulo, ano 10, n. 29, p. 175-200, 1995.

FIGUEIREDO, Argelina Cheibub; LIMONGI, Fernando; VALENTE, Ana Luzia. Governabilidade e concentração de poder institucional: o Governo FHC. Tempo Social, Rev. Sociol. USP, São Paulo, v. 11, n. 2, p. 49-62, out. 1999.

GENOINO, José. Revisão constitucional e reforma do Congresso. In: O desafio do Congresso Nacional: mudanças internas e fortalecimento institucional. Cadernos de Pesquisa CEBRAP, São Paulo, n. 3, p. 7-13, nov. 1994.

GOMES, Sandra. O impacto das regras de organização do processo legislativo no comportamento dos parlamentares: um estudo de caso da Assembleia Nacional Constituinte (1987-1988). DADOS - Revista de Ciências Sociais, Rio de Janeiro, v. 49, n. 1, p. 193-224, 2006.

JOBIM, Nelson. O Colégio de Líderes e a Câmara dos Deputados. In: O desafio do Congresso Nacional: mudanças internas e fortalecimento institucional. Cadernos de Pesquisa CEBRAP, São Paulo, n. 3, p. 37-59, nov. 1994.

JOBIM, Nelson. O Colégio de Líderes. 27. out. 2011. Entrevista concedida a Juliana Baldoni Figueiredo. Brasília: 2011. 
LIMONGI, Fernando. A democracia no Brasil. Presidencialismo, coalizão partidária e processo decisório. Revista Novos Estudos - CEBRAP, São Paulo, n. 76, p. 17-41, nov. 2006.

MAINWARING, Scott. Democracia presidencialista multipartidária: o caso do Brasil. Lua Nova: Revista de Cultura e Política, São Paulo, n. 28-29, abr. 1993.

MÜLLER, Gustavo. Comissões e Partidos Políticos na Câmara dos Deputados: um estudo sobre os padrões partidários de recrutamento para as comissões permanentes. DADOS - Revista de Ciências Sociais, Rio de Janeiro, v. 48, n. 1, p. 371-394, 2005.

NOVAES, Carlos Alberto M. Individualismo e partidos na Câmara dos Deputados. Revista Novos Estudos — CEBRAP, São Paulo, n. 38, p. 99-147, mar. 1994.

PAIVA, Mozart Vianna de. O Colégio de Líderes: 24 out. 2011. Entrevista concedida a Juliana Baldoni Figueiredo. Brasília: 2011.

PERTENCE, Sepúlveda. Voto de liderança - inconstitucionalidade. Revista de Direito Público, n. 92, p. 116-121, out.-dez. 1989.

QUINTELA, Sérgio F. Partidos políticos: representatividade e governabilidade. Carta Mensal, Rio de Janeiro, v. 51, nº 610, p. 51-54, jan. 2006.

RODRIGUES, Ricardo José. O papel do Colégio de Líderes no processo legislativo da Câmara dos Deputados. Revista Brasileira de Estudos Políticos, Belo Horizonte, n. 83, p. 131-146, jul. 1996.

SANTOS, Fabiano. Partidos e comissões no presidencialismo de coalizão. DADOS - Revista de Ciências Sociais, Rio de Janeiro, v. 45, n. 2, p. 237-264, 2002.

SARTORI, Giovanni. Nem presidencialismo, nem parlamentarismo. Revista Novos Estudos CEBRAP, São Paulo, n. 35, mar. 1993.

SOARES, Rosineth Monteiro. Liderança Parlamentar. Revista de Informação Legislativa, Brasília, v. 30, n. 118, p. 333-348, abr.-jun. 1993.

TEIXEIRA, Miro. O Colégio de Líderes. 23. nov. 2011. Entrevista concedida a Juliana Baldoni Figueiredo. Brasília: 2011.

VIANA, Prisco. O processo legislativo: partidos e grupos congressuais. In: O desafio do Congresso Nacional: mudanças internas e fortalecimento institucional. Cadernos de Pesquisa CEBRAP, São Paulo, n. 3, p. 15-36, nov. 1994.

VIEIRA, Fernando Sabóia. Poderes e atribuições do Presidente da Câmara dos Deputados no processo decisório legislativo. 2009. 96 f. Dissertação (Mestrado em Ciência Política) Instituto de Pesquisas Universitárias do Rio de Janeiro e Centro de Formação, Treinamento e Aperfeiçoamento da Câmara dos Deputados, Rio de Janeiro, 2009.

Artigo recebido em: 11/04/2012

Artigo aceito para publicação em: 09/05/2012 